\title{
Optimum Seawater Depth in Modified Solar Still Using Vertical Flax Porous Media
}

\author{
Ahmed H. Mohamed \\ Department of Mechanical Engineering \\ Faculty of Engineering, South Valley \\ University \\ Qena, Egypt \\ A.H.Mohammed@eng.svu.edu.eg
}

\author{
Ahmed N. Shmroukh \\ Department of Mechanical Engineering \\ Faculty of Engineering, South Valley \\ University \\ Qena, Egypt \\ eng_ahmednagah@yahoo.com
}

\author{
M.attalla \\ Department of Mechanical Engineering \\ Faculty of Engineering, South Valley \\ University \\ Qena, Egypt \\ moha_attalla@yahoo.com
}

\begin{abstract}
The world need for portable water is continuously growing because of industrial population and agricultural growth. Solar still is available device that can be used for desalination of brackish and saltwater for drinking purposes. In this work, we study the investigation of the influence of change of depth of saline water inside basin of single slope solar still under the weather condition of south valley university, faculty of engineering, Qena, Egypt (Latitude:26.15878 ${ }^{\circ}$, Longitude:32.71081 ${ }^{\circ}$ ). And tested at real day time 8A.M to 6P.M on different five days from 20/8/2019 to24/8/2019, for different five water depths $(0.5,1,2,3$, and $5 \mathrm{~cm})$, and used vertical flax porous media to enhance the performance of solar still. Result showed that the freshwater productivity at depth of water $0.5 \mathrm{~cm}$ higher than other depths $(1,2,3,5 \mathrm{~cm})$. In addition, maximum productivity of freshwater for simple model and modification model 3480 and $4600 \mathrm{ml} / \mathrm{m} 2 /$ day respectively.
\end{abstract}

Keywords - solar still, desalination, depth of water.

\section{INTRODUCTION}

Water scarcity has become a major constraint to economic development and threat to livelihood in increasing parts of the world. Since the late 1980s, water scarcity research has attracted much political and public attention(Junguo Liu, Pfister et al. 2017). As the demand increases, so too does the importance of water. This is clearly the case in Egypt, where rainfall is rare and the governmentally enforced quota for withdrawal from the Nile River has not changed since 1959. The water demand has multiplied as a result of population growth, agricultural expansion, as well as industrial development and a rise in the standard of living(Allam 2007). Solar desalination is one of the options to produce fresh water from any type of contaminated water (brackish, contaminated and sea water) in a sustainable way. A solar still is a simple device used to purify the water using solar energy through evaporation and condensation processes. In general, the productivity of the conventional single solar still (CSSS) is about 2-5 1/m²/day (T. Arunkumar and Li Xuan 2019). Table1 showed many studies done on solar still to improve the productivity. The most important study shows that the Glass-water temperature difference Increasing the difference in temperature between the glass cover and the basin water leads to an increase in the natural circulation of the air mass inside the solar still.(S.W. Sharshir 2016).

\section{EXPERIMENTAL SET UP}

\section{A. Principle of solar distillation}

A basin of solar still has a thin layer of water, a transparent

Glass cover that cover the basin and channel for collecting
Table 1 summary of the mentioned studies in the review of brine depth effect

\begin{tabular}{|c|c|c|c|c|c|}
\hline Author(s) & Productivity & $\begin{array}{l}\text { Type of } \\
\text { still }\end{array}$ & $\begin{array}{l}\text { Brine } \\
\text { depth } \\
\text { range }\end{array}$ & Location & $\begin{array}{c}\text { Data of } \\
\text { test }\end{array}$ \\
\hline $\begin{array}{c}\text { (M.K. } \\
\text { Phadatare } \\
\text { 2007) }\end{array}$ & $\begin{array}{l}2.1 \mathrm{~L} / \mathrm{m} 2 / \text { day } \\
\text { At depth } 2 \mathrm{~cm}\end{array}$ & $\begin{array}{c}\text { SSSS } \\
\text { plastic } \\
\text { solar still } \\
\end{array}$ & $2: 12 \mathrm{~cm}$ & India & $\begin{array}{c}6- \\
20 / 1 / 2200 \\
6 \\
\end{array}$ \\
\hline $\begin{array}{c}\text { (Rahul } \\
\text { Dev 2011) }\end{array}$ & $\begin{array}{l}6.302,5.576 \\
\text { and } 4.299 \\
\mathrm{~kg} / \mathrm{m} 2 \text {-day }\end{array}$ & $\begin{array}{c}\text { inverted } \\
\text { absorber } \\
\text { solar still } \\
\text { (IASS) }\end{array}$ & $\begin{array}{c}0.01, \\
0.02 \text { and } \\
0.03 \mathrm{~m}\end{array}$ & $\begin{array}{c}\text { Muscat, } \\
\text { Oman } \\
(23370 \mathrm{~N} \\
\text { latitude, } \\
58350 \mathrm{E} \\
\text { longitude) }\end{array}$ & July 2009. \\
\hline $\begin{array}{l}\text { (M.R. } \\
\text { Rajamanic } \\
\text { kam } \\
2012)\end{array}$ & $\begin{array}{c}3.07 \\
\mathrm{~L} / \mathrm{m} 2 / \text { day at } \\
\text { depth } 0.01 \mathrm{~m}\end{array}$ & $\begin{array}{c}\text { single } \\
\text { basin } \\
\text { double } \\
\text { slope (DS) } \\
\text { solar still } \\
\end{array}$ & $\begin{array}{c}0.01 \mathrm{~m}, \\
0.025 \mathrm{~m}, \\
0.05 \mathrm{~m} \\
\quad \text { and } \\
0.075 \mathrm{~m} \\
\end{array}$ & $\begin{array}{c}\text { Annamalai } \\
\text { University, } \\
\text { India }\end{array}$ & $\begin{array}{c}11.02 .2011 \\
\text { to } \\
19.02 .2011\end{array}$ \\
\hline $\begin{array}{l}\text { (T.Elango } \\
\text { 2015) }\end{array}$ & $\begin{array}{c}\text { double basin } \\
\text { insulated and } \\
\text { un-insulated } \\
\text { stills gave } \\
17.38 \% \text { and } \\
8.12 \% \text { higher } \\
\text { production } \\
\text { than the } \\
\text { single basin } \\
\text { still } \\
\end{array}$ & $\begin{array}{l}\text { Single and } \\
\text { double } \\
\text { basin } \\
\text { double } \\
\text { slope solar } \\
\text { stills }\end{array}$ & $1 \mathrm{~cm}$ & $\begin{array}{c}\text { National } \\
\text { Engineerin } \\
\mathrm{g} \\
\text { College, } \\
\text { Kovilpatti } \\
\left(9^{\circ} 11^{\prime} \mathrm{N},\right. \\
\left.77^{\circ} 52^{\prime} \mathrm{E}\right) \\
\text { Tamil } \\
\text { Nadu, } \\
\text { India } \\
\end{array}$ & $\begin{array}{c}\text { March- } \\
\text { April } 2014\end{array}$ \\
\hline $\begin{array}{l}\text { (A.E. } \\
\text { Kabeela } \\
\text { and } \\
\text { Hitesh } \\
\text { Panchal } \\
\text { 2019) }\end{array}$ & $\begin{array}{c}\text { Productivity } \\
\text { of absorber } \\
\text { plate with and } \\
\text { without } \\
\text { coating was } \\
\text { found to be } \\
6.6 \text { and } 6.2 \\
\mathrm{~kg} / \mathrm{m} 2 \\
\text { respectively } \\
\text { at } 1 \mathrm{~cm} \text { water } \\
\text { depth }\end{array}$ & $\begin{array}{c}\mathrm{TiO} 2 \text { nano } \\
\text { black paint } \\
\text { coated } \\
\text { pyramid } \\
\text { solar still }\end{array}$ & $\begin{array}{l}\text { varied } \\
\text { from } 1 \\
\mathrm{~cm} \text { till } \\
3.5 \mathrm{~cm} \\
\text { on a } \\
\text { basin }\end{array}$ & $\begin{array}{l}\text { under the } \\
\text { climatic } \\
\text { condition } \\
\text { of } \\
\text { Chennai. } \\
\text { S.A. } \\
\text { Engineerin } \\
\text { g College }\end{array}$ & $\begin{array}{c}\text { February2 } \\
018\end{array}$ \\
\hline $\begin{array}{l}\text { (Rajesh } \\
\text { Trioathi } \\
\text { 2005) }\end{array}$ & $\begin{array}{c}\text { Yield } \\
\text { decrease with } \\
\text { increase water } \\
\text { depth }\end{array}$ & $\begin{array}{c}\text { Active } \\
\text { solar still } \\
\text { coupled } \\
\text { with flat } \\
\text { plate } \\
\text { collector } \\
\end{array}$ & $\begin{array}{c}0.05 \mathrm{~m} \\
0.1 \mathrm{~m} \\
\text { and } \\
0.15 \mathrm{~m}\end{array}$ & & \\
\hline $\begin{array}{l}\text { (Hamed } \\
\text { Taghvaei } \\
\text { 2015) }\end{array}$ & $\begin{array}{c}\text { Decreasing } \\
\text { the brine } \\
\text { depth reduced } \\
\text { both the } \\
\text { production } \\
\text { and efficiency } \\
\text { of active solar } \\
\text { stills }\end{array}$ & $\begin{array}{l}\text { Active } \\
\text { solar still } \\
\text { coupled } \\
\text { with flat } \\
\text { plate } \\
\text { collector }\end{array}$ & $\begin{array}{l}10,8.5 \\
7,5.5 \\
4 \mathrm{~cm}\end{array}$ & $\begin{array}{c}\text { latitude of } \\
29^{\circ} 37^{\prime} \mathrm{N} \\
\text { and } \\
\text { longitude } \\
\text { of } \\
52^{\circ} 32^{\prime} \mathrm{E} \text { in } \\
\text { southern } \\
\text { Iran. }\end{array}$ & September \\
\hline $\begin{array}{c}\text { (Abd } \\
\text { Elnaby } \\
\text { Kabeel, } \\
\text { Ravishank } \\
\text { ar } \\
\text { Sathyamu } \\
\text { rthy et al. } \\
\text { 2019) } \\
\end{array}$ & $\begin{array}{c}\text { CSS-ISS, } \\
\text { ISS, and CSS } \\
\text { were } 6.2 \text {, } \\
5.04 \text {, and } 4.24 \\
\text { kg, }\end{array}$ & $\begin{array}{l}\text { convention } \\
\text { al solar } \\
\text { still } \\
\text { integrated } \\
\text { with } \\
\text { inclined } \\
\text { solar still }\end{array}$ & $\begin{array}{c}0.02 \mathrm{~m} \\
\text { and } \\
0.04 \mathrm{~m}\end{array}$ & & \\
\hline
\end{tabular}


The distillate water from solar still. The glass transmits the sun rays through it and saline water in the basin or solar still is heated by solar radiation which passes through the glass cover and absorbed by the bottom of the solar still. In a solar still, the temperature difference between the water and glass cover is the driving force of the pure water yield. It influences the rate of evaporation from the surface of the water within the basin flowing towards condensing cover. Vapor flows upwards from the hot water and condense. This condensate water is collected through a channel(Naga Sarada Somanchi and Sai Phanindra Dinesh Kakarlamudi 2015).

\section{B. Distillation unit}

Two identical unit, model (A) represent solar still with flax porous media and model (B) represent solar still without flax, as shown in figure (1.2). Solar still consists of a metallic box having four sides. These sides are made of steel sheet, $2 \mathrm{~mm}$ thick. The base of each unit is painted black to increase the solar absorptivity. The outside walls and the base of each unit are insulated with glass wool, $4 \mathrm{~cm}$ thick. The condensing surface in each still unit is a glass cover, $5 \mathrm{~mm}$ thick with angle $26^{\circ}$. The glass covers of each still box is adjusted on the edge of the rectangular sides. Silicon rubber sealant is used to prevent leakage from any gap between the glass covers and still box. A collection trough is used for each still box to collect the condensed water. The amount of distilled water is measured at hourly intervals.

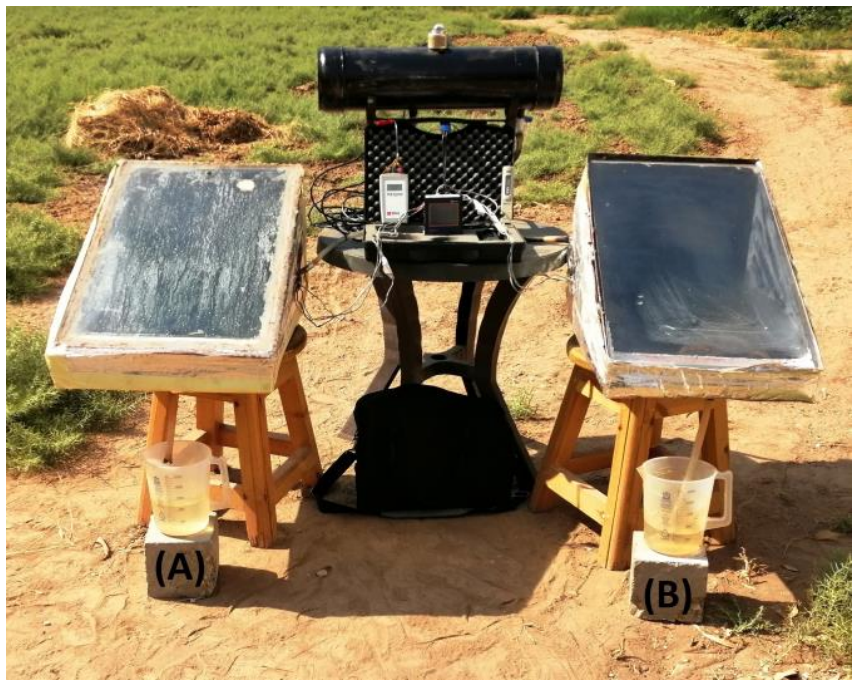

Figure 1Photographic view of the stills. (A) solar still with flax and (B) without flax porous media.

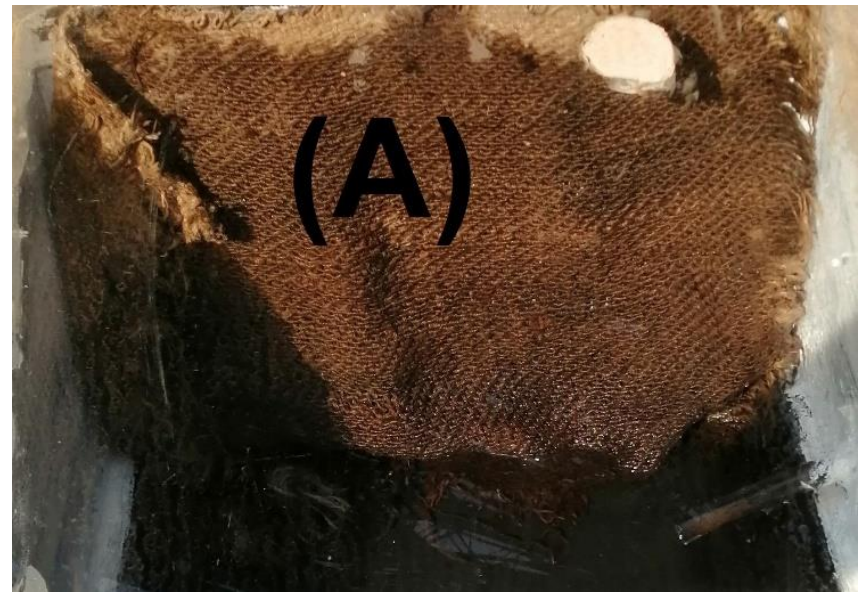

Figure 2 photographic view of flax porous media

\section{Instrumentation}

Water, glass, outside air temperatures and solar radiation are measure by following instruments in table 2 .

Table 2 insrtruments properties of the experimental test.

\begin{tabular}{|c|c|c|c|c|c|}
\hline S.NO & instrument & $\begin{array}{l}\text { Manufactu } \\
\text { rer/model }\end{array}$ & $\begin{array}{l}\text { Rang } \\
\text { e }\end{array}$ & $\begin{array}{l}\text { Erro } \\
\mathbf{r}\end{array}$ & Accuracy \\
\hline 1 & Thermocouple & K-type & $\begin{array}{l}0- \\
1000^{\circ} \\
\mathrm{C}\end{array}$ & $\begin{array}{l} \pm 0.4 \\
\%\end{array}$ & $\pm 1.1^{\circ} \mathrm{C}$ \\
\hline 2 & Data recorder & Multi Con & $\begin{array}{l}16 \\
\text { port }\end{array}$ & $\begin{array}{l}\ldots \ldots \\
\ldots \ldots\end{array}$ & $\begin{array}{l}\text { …........ } \\
\text { …... }\end{array}$ \\
\hline 3 & $\begin{array}{l}\text { Digital } \\
\text { pyranometer }\end{array}$ & $\begin{array}{l}\text { Kipp \& } \\
\text { Zonen CM4 }\end{array}$ & $\begin{array}{l}0- \\
4000 \\
\mathrm{w} / \mathrm{m}^{2} \\
\end{array}$ & $\begin{array}{l} \pm 0.93 \\
\%\end{array}$ & $\pm 20 \mathrm{w} / \mathrm{m}^{2}$ \\
\hline 4 & Beaker & $\begin{array}{l}\text { PLASTI } \\
\text { BRAND } \\
\text { Germany }\end{array}$ & $\begin{array}{l}0- \\
200 \mathrm{ml}\end{array}$ & $\begin{array}{l} \pm 0.12 \\
\%\end{array}$ & $\pm 0.1 \mathrm{ml}$ \\
\hline 5 & $\begin{array}{l}\text { Total dissolved } \\
\text { solid meter }\end{array}$ & China & $\begin{array}{l}0- \\
9990 \\
\text { ppm }\end{array}$ & $\pm 2 \%$ & $\pm 10 \mathrm{ppm}$ \\
\hline
\end{tabular}

\section{RESULTS AND DISCUSSION}

The ambient, glass, water temperatures and solar radiation it has a big role in the solar still performance. Fig. 3 shows variation solar radiation for five days of tests from 20/8/2019 to $24 / 8 / 2019$ and recorded that the maximum solar radiation 947,926,908,1004W/m ${ }^{2} \quad{ }^{\circ} \mathrm{C}$, respectively. Fig.4 shows variation of ambient air temperature (Ta) also for same day test. And recorded the maximum air temperature for five-day test $41,42,37,38,44^{\circ} \mathrm{C}$. Fig. 5 shows the variation of water temperature (Tw) during all experiments and observed that water temperature in case $0.5 \mathrm{~cm}$ depth of basin water higher than other $(5,3,2,1) \mathrm{cm}$ that because the amount of water less and need less latent heat energy to evaporation the water. In case $5 \mathrm{~cm}$ and $3 \mathrm{~cm}$ depth of basin water tests, observed that through Interval time $2: 00 \mathrm{pm}$ to $6: 00 \mathrm{pm}$ the water temperature at experiment of $0.5 \mathrm{~cm}$ and $1 \mathrm{~cm}$ is less than $5 \mathrm{~cm}$ and $3 \mathrm{~cm}$ that because thermal energy storage inside the body of solar still and also inside water that energy release during 
the disappearance of the sun. Fig.6 shows the relationship in case modification model (solar still with flax) between glass, water and porous media (flax) temperature during 24/8/2019 where depth of basin water $0.5 \mathrm{~cm}$. Fig. 7 shows the relationship between glass and water temperature in case simple model (solar still without flax). In fig.6 it is observed that glass temperature higher than water that blocked and reversed the vapor circulation inside still and reduce the productivity of fresh water, using flax porous media that help and can solve this problem. In fig. 6 observed that water temperature higher than the glass temperature at almost time period that because the effect of wet flax help to decrease the glass temperature to make natural circulation of vapor to increase the condensation lead to increase the productivity. From fig. (6.7) we can say that glass, water temperature it's important parameter solar still Depended on it, increasing the difference in temperature between the glass cover and the basin water lead to an increase in the natural circulation of the air mass inside the solar still.

Fig. 8 shows the relationship between time in hours and accumulated productivity in $\mathrm{ml}$ in all test days at modification model and observed that the accumulated productivity at $0.5 \mathrm{~cm}$ depth of water test higher than others $(5,3,2,1 \mathrm{~cm})$ depth of water tests. That because the latent heat of vaporization in case $0.5 \mathrm{~cm}$ it's less than others that make evaporation higher leading to higher productivity. The maximum accumulated productivity recorded for modification model and simple model at depth of water $0.5 \mathrm{~cm}$ it's $4600 \mathrm{ml}$. Fig.9 shows also the relationship accumulated productivity of fresh water and time in case simple model. And observed that the maximum productivity at $0.5 \mathrm{~cm}$ depth of water it's $3480 \mathrm{ml}$.

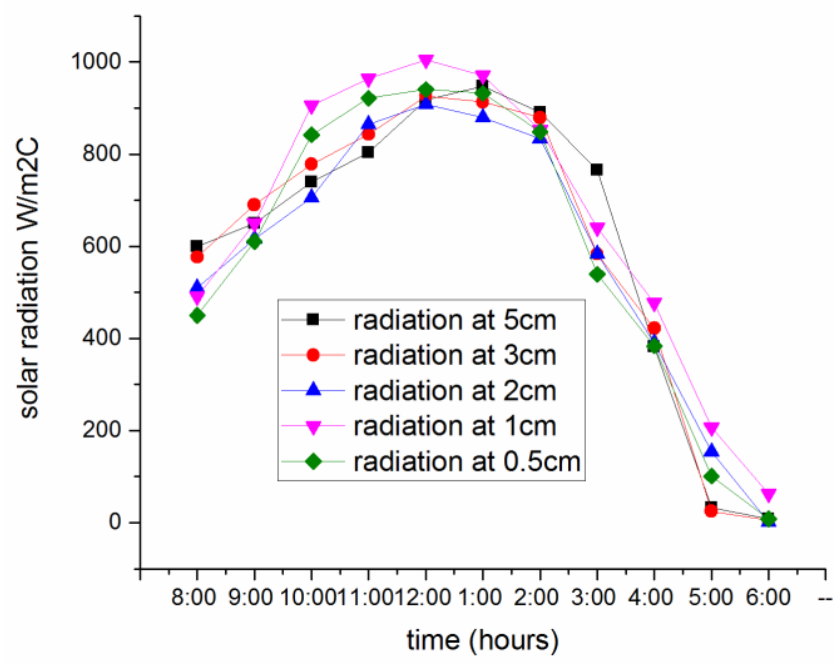

Figure 3variation of solar radiation at all experiments.

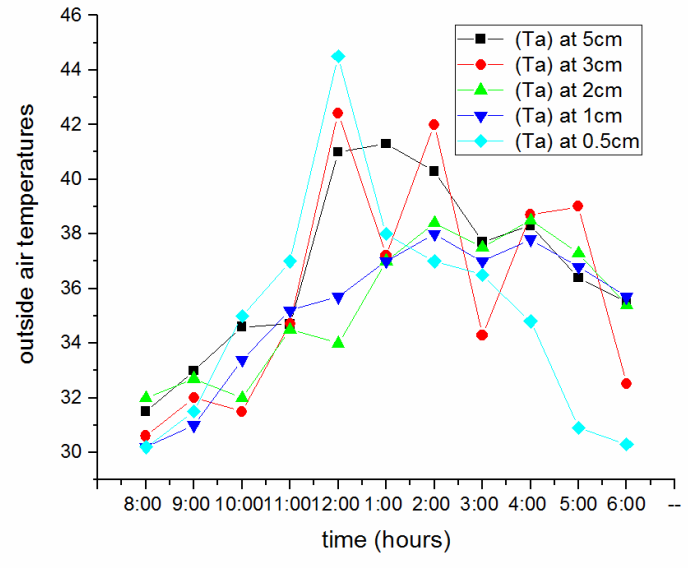

Figure 4variation of air temperature at all experiments.

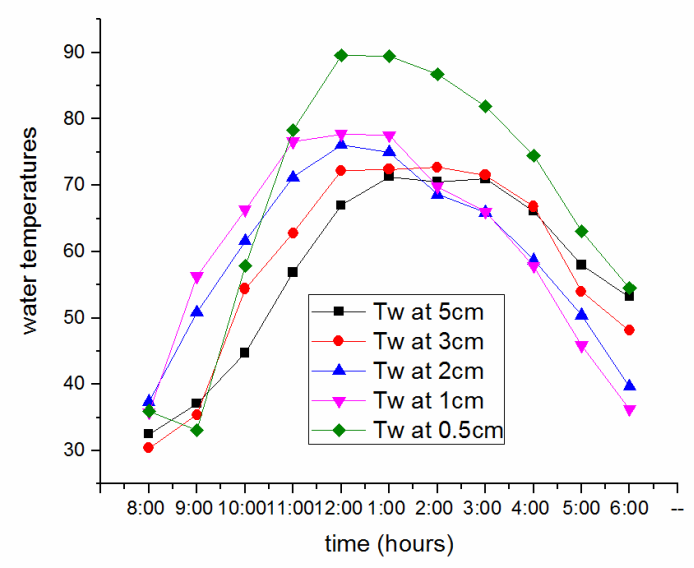

Figure 5 variation of water temperature at all experiments.

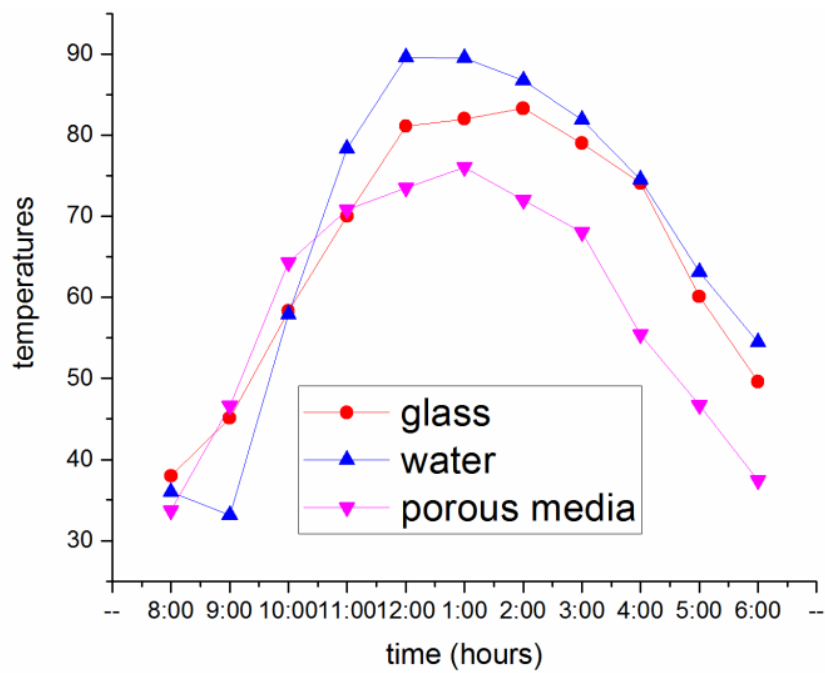

Figure 6 relationship between glass, water, porous media temperature at $0.5 \mathrm{~cm}$ depth of water. 


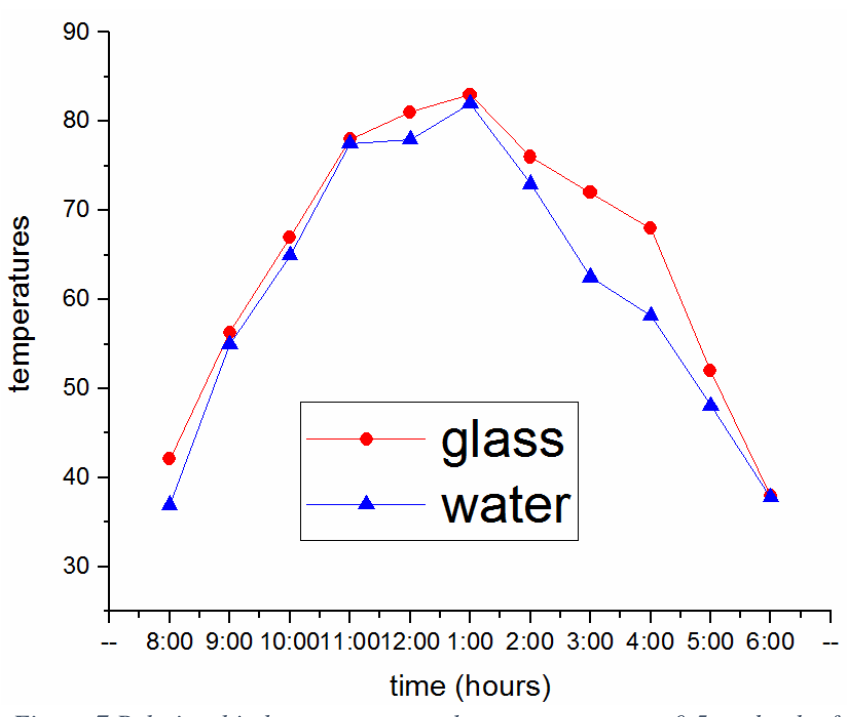

Figure 7 Relationship between water, glass temperature at $0.5 \mathrm{~cm}$ depth of water.

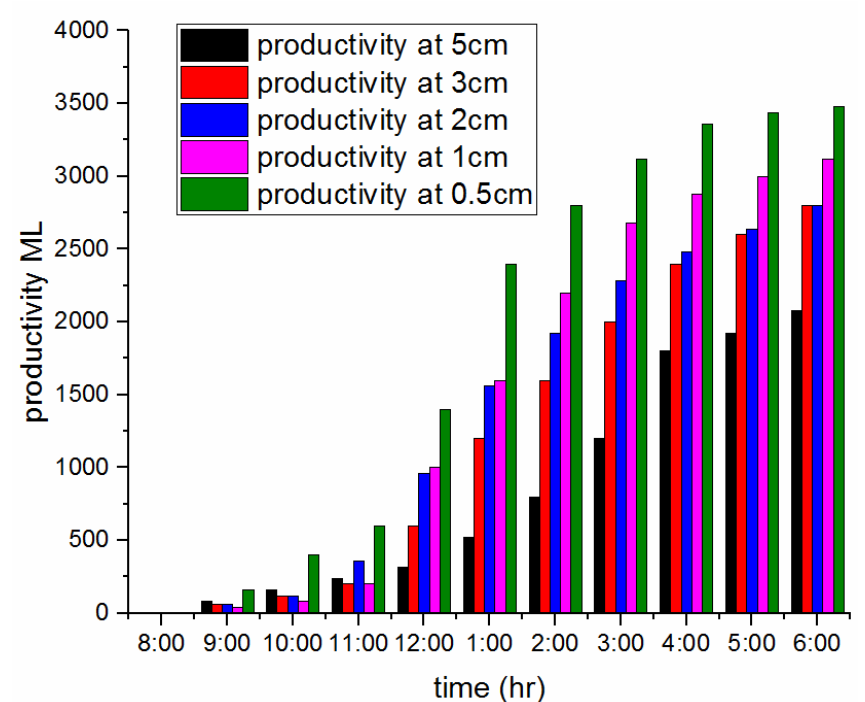

Figure 9 variation of time in hour and accumulated productivity at simple model.

\section{CONCLUSION}

In the present study a single slope solar still is experimentally analyzed on the performance with flax porous media solar still with conventional one and tested for Qena Egypt climatic condition. accumulated yield per unit meter square are of solar still with and without flax porous media under a constant water depth of $0.5 \mathrm{~cm}$ within the basin were observed as 4600 and $3480 \mathrm{ml}$ respectively. And resulted shown that productivity at depth $0.5 \mathrm{~cm}$ higher than other depths $(1.2 .3 .5 \mathrm{~cm})$ where total dissolved solids $110 \mathrm{ppm}$. The use of porous material has provided the difference in glass and water temperatures resulting in increased productivity.

\section{REFERENCES}

[1] A.E. Kabeela, R. S., Swellam W. Sharshirc, A. Muthumanokar, and N. P. Hitesh Panchal, C. Prasad, S. Nandakumar, M.S. El Kady (2019). "Effect of water depth on a novel absorber plate of pyramid solar still coated with $\mathrm{TiO} 2$ nano black paint." Journal of Cleaner Production 213: 185-191.

[2] Abd Elnaby Kabeel, Y. T., P. N. K. Ravishankar Sathyamurthy, et al. (2019). "Experimental study on conventional solar still integrated with inclined solar still under different water depth." Heat Transfer-Asian Research 48(1): 100114.

[3] Allam, M. N. A. G. I. (2007). "Water resources in Egypt: future challeges and opportunities." Water International 32(2): 205-218.

[4] Hamed Taghvaei, H. T., Khosrow Jafarpur, Mehrzad Feilizadeh, M.R. Karimi Estahbanati (2015). "Experimental investigation of the effect of solar collecting area on the performance of active solar stills with different brine depths." Desalination 358: 76-83.

[5] Junguo Liu, H. Y., Simon N. Gosling, Matti Kummu, Martina Flörke, Stephan, N. H. Pfister, Yoshihide Wada, Xinxin Zhang, Chunmiao Zheng,, et al. (2017). "Water scarcity assessments in the past, present and future." Earths Future 5(6): 545-559.

[6] M.K. Phadatare, S. K. V. (2007). "Influence of water depth on internal heat and mass transfer in a plastic solar still." Desalination 217(1-3): 267-275. 
[7] M.R. Rajamanickam, A. R. (2012). "Influence of Water Depth on Internal Heat and Mass Transfer in a Double Slope Solar Still." Energy procedia 14: 1701-1708.

[8] Naga Sarada Somanchi, S. L. S. S., Thotakura Ashish Kumar, and A. P. Sai Phanindra Dinesh Kakarlamudi (2015). "Modelling and Analysis of Single Slope Solar Still at Different Water Depth." Aquatic Procedia 4: 1477-1482.

[9] Rahul Dev, S. A.-w., G.N. Tiwari (2011). "Performance study of the inverted absorber solar still with water depth and total dissolved solid." Applied Energy 88(1): 252-264.

[10] Rajesh Trioathi, G. N. T. (2005). "Effect of water depth on intemal heat and mass transfer for active solar distillation." Desalination 173: 187-200.
[11] S.W. Sharshir, N. Y., Guilong Peng, A.E. Kabeel (2016). "Factors affecting solar stills productivity and improvement techniques: A detailed review." Applied Thermal Engineering 100: 267-284.

[12] T. Arunkumar, K. R., D. Dsilva Winfred Rufuss, David Denkenberger, Guo Tingting, and R. V. Li Xuan (2019). "A review of efficient high productivity solar stills." Renewable and Sustainable Energy Reviews 101: 197220

[13] T.Elango, K. k. M. (2015). "The effect of the water depth on the productivity for single and double basin double slope glass solar stills." Desalination 359: 82-91. 